\title{
Modeling Constructed Wetlands for Hot and Arid Regions: Model Development
}

\section{Harry Zahakos ( $\nabla$ hzahakos@gmail.com )}

ERM https://orcid.org/0000-0002-6436-9232

\section{Suhur Saeed}

ExxonMobil Reseaerch Qatar

\section{Venkat S. Kolluru}

Environmental Resource Management

\section{Shwet Prakash}

ERM

\section{Linso Varghese}

ExxonMobil Research Qatar

\section{Stephane Prigent}

Bauer Nimr LLC

\section{Research Article}

Keywords: Constructed wetland, Contaminant fate modeling, Hot arid climate, Produced water, Process water, Water treatment, reuse

Posted Date: November 30th, 2021

DOI: https://doi.org/10.21203/rs.3.rs-1040499/v1

License: (c) (i) This work is licensed under a Creative Commons Attribution 4.0 International License.

Read Full License 


\title{
Modeling Constructed Wetlands for Hot and Arid Regions: Model Development
}

\author{
Harry A. Zahakos ${ }^{a, 1}$, Suhur Saeed ${ }^{b}$, Venkat S. Kollurua, Shwet Prakasha, Linso \\ Varghese $^{b}$, Stephane Prigent ${ }^{c}$ \\ ${ }^{a}$ Water Resource and Modeling Group, Environmental Resource Management, 75 Valley Stream Parkway, Malvern, PA 19355 USA \\ ${ }^{b}$ ExxonMobil Research Qatar, Doha, Qatar \\ 'BAUER Nimr LLC, P.O.Box 1186, P.C 114, Al Mina, Muscat, Sultanate of Oman
}

\begin{abstract}
A mechanistic model was developed to assist with design of constructed wetlands intended to treat industrial wastewater in the Arabian Gulf region. The model is deterministic in nature and thus allows explicit evaluation of the fate and transport of wastewater constituents throughout constructed wetlands to assess their efficacy in treatment. Although the model was developed for the purpose of evaluating treatment wetlands in the hot and arid climate of the Middle East, the model is generalized in order to allow users to simulate a wide range of climates, any type of wetland, with any configuration, and any selection of material and plants. The model simulates the majority of physical, chemical, and biological processes that could occur in wetlands that are responsible for the removal of constituents. The model is designed to be flexible enough to allow the simulation of any number pre-selected constituents or other constituents of the user's choice made based on the quality of influent. The model relies on a large body of existing literature to formulate each process. The model development discussed in this report and the resulting model, CWM, is considered "in progress". During the present stage, the model framework and algorithms have been developed and made functional. Subsequently, model formulations will need to be validated, model limitations analyzed and addressed, and model refinements made, before and during use in full-scale operations and design. As such, it is recognized
\end{abstract}

\footnotetext{
${ }^{1}$ Corresponding author. Email address: hzahakos@gmail.com
} 
that the present stage of model development is "experimental", and future refinements of the model are anticipated. Model results at this time consist of evaluation of key model features and how they perform in Middle Eastern climates.

Keywords: Constructed wetland; Contaminant fate modeling; Hot arid climate; Produced water; Process water; Water treatment and reuse

\section{Contents}

Abstract.

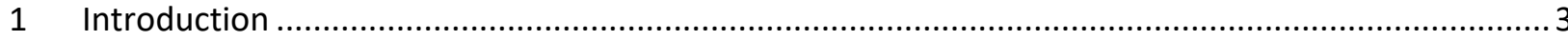

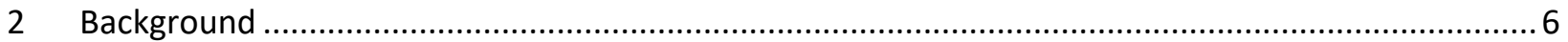

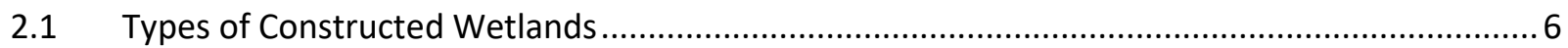

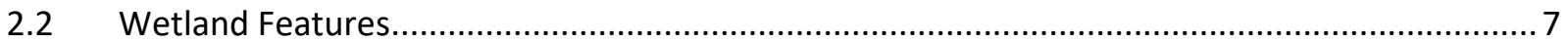

2.3 Wetland Performance in Hot and Arid Climates................................................................ 8

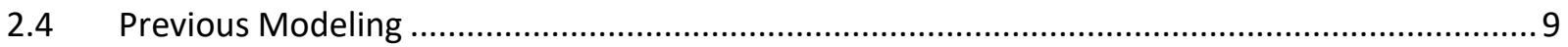

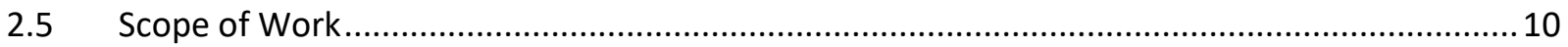

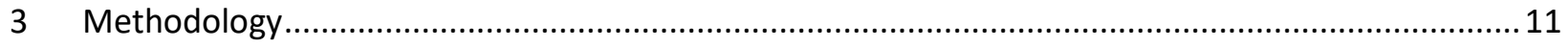

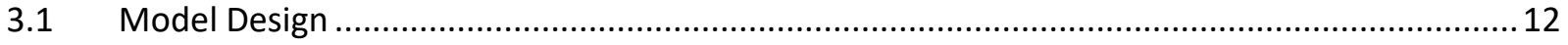

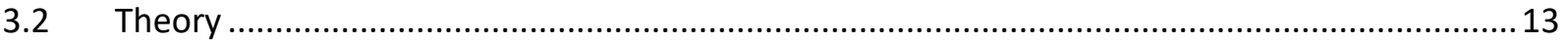

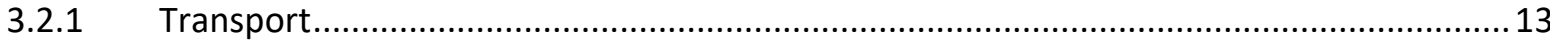

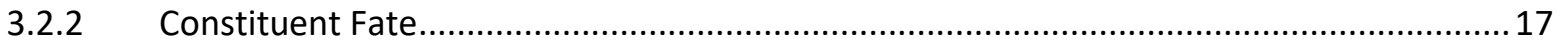

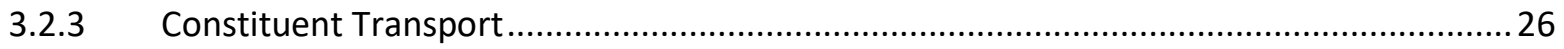

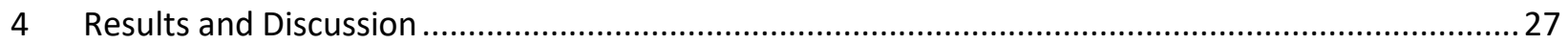


4.1.1 Temperature

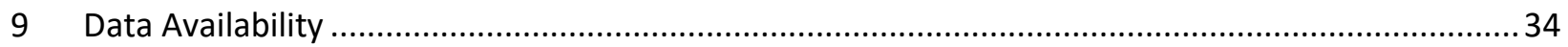

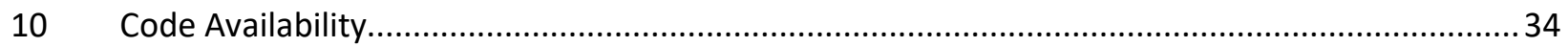

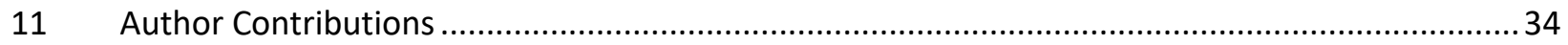

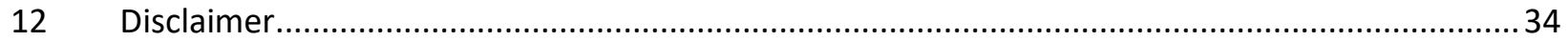

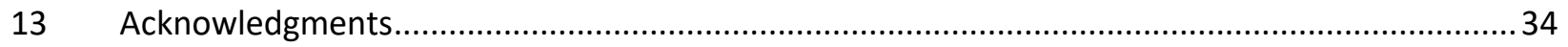

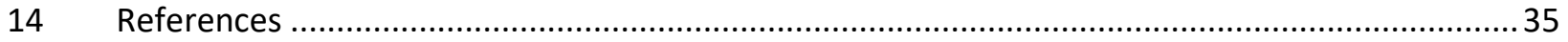

\section{$1 \quad$ INTRODUCTION}

Water scarcity has long been a persistent challenge in the Arabian Peninsula. Due to the arid and often hyper-arid conditions, the majority of countries in the region are classified as having extreme water scarcity. This situation is worsening due to growing population, agriculture, urbanization and industrialization (Stefanakis, 2020). Moreover, it is expected that climate change will further exacerbate the situation with increased temperature and evaporation and reduced precipitation. Therefore, there is 
a recent vision and initiative to recycle domestic and industrial wastewater and the green technology of Constructed Wetlands (CWs) have been proposed as an appropriate technology to address the main issues in the wastewater sector in this region (Stefanakis, 2020). As discussed in this paper, the use of CWs is particularly suited to the region due to enhanced performance under the warm temperatures of the region.

The value of natural wetlands in water quality improvement has long been recognized (Kadlec and Wallace, 2009; Mitsch and Gosselink, 2007). After some of the earliest studies of the use of wetlands to treat municipal wastewater (Odum, 1985; Marshall, 1971), civil engineers began the implementation of constructed wetlands to further this practice (Spangler, et al, 1976; James and Bogart, 1989). Over the years, considerable knowledge has been gained about how these complex systems work (Moshiri, 1993; Kadlec and Wallace, 2009), and so has the knowledge needed to design these systems. Constructed wetlands have been successfully used to treat a various types of wastewater (Vymazal, 2009) including municipal wastewater (Sudarsan, et al, 2018), urban stormwater runoff (Scholz, 2006), industrial wastewater (Knight, et al., 1999), agricultural runoff (Vymazal and Brezinova, 2015), and mine discharge (Wieder, 1989; Eger and Wagner, 2002).

Wetlands are complex systems; the water quality benefits achieved by wetlands rely on natural microbial, biological, physical, and chemical processes to treat wastewater. Constructed wetlands, similar to natural wetlands, act as a watershed filter, a sink for sediments and precipitates, and a biogeochemical engine that recycles and transforms nutrients. A constructed wetland can perform many of the functions of conventional wastewater treatment systems such as sedimentation, filtration, digestion, oxidation, reduction, adsorption, and precipitation (Kadlec and Wallace, 2009; USEPA, 2000; Brix, 1993; Chu and Rediske, 2012; Tchobanoglous, 1993). Many of these individual mechanisms have been well-studied, however few studies address the role each plays in an integrative fashion. 
The overall aim of this study was to assist in design of treatment wetlands for industrial wastewater reuse that is appropriate for the Arabian Gulf region. The Constructed Wetland Model (CWM) is therefore designed to assist in selecting from a choice of designs such that effluent levels can be achieved pursuant to applicable standards. The model was specifically developed to allow key effluent water quality parameters, such as suspended solids, organic matter, pathogens, and in some instances, nutrients, and heavy metals, to be directly evaluated against target levels for reuse.

There exist numerous guidelines for the design of constructed wetlands (ITRC, 2003; RREL, 1993; IDEM, 1997; UN-HABITAT, 2008). While there are simplified models that can be used to describe the performance of existing operational wetlands (Kadlec, 2000), there are few mechanistic models available. Mechanistic models are an important tool to understand the various wetland processes, identify which processes drive treatment efficacy, and therefore be of great assistance to wastewater managers in the design of these systems. The intent of this paper is to present the development of a model of constructed wetlands to address this growing need. Although developed to address wetlands in Middle Eastern climates, because the CWM is mechanistic in nature, it is generalized so as to be capable of simulating a wide range of wetlands and climates. The model is based on a combination of existing frameworks available for modeling of surface and sub-surface flows, and theoretical concepts of various fate processes available in the literature.

The model includes a graphical user interface that allows the user to input physical characteristics of the wetland design (e.g., regions of substrate, length, depth, gradient, hydraulic head, porosity, transmissivity, etc.), environmental parameters (air temperature, relative humidity, wind speed), input water characteristics (e.g., flow rate, temperature, constituent concentrations), as well as values for all key parameters associated with the algorithms used within the model to predict flow and the fate/transport of target components (nutrient and non-nutrient); as well as output data and visualization options. 


\subsection{TYPES OF CONSTRUCTED WETLANDS}

Constructed wetlands can typically be classified into two types of systems: free water surface (FWS) wetlands or vegetated submerged bed (VSB) wetlands (USEPA, 2000). A surface flow (FWS) wetland, as shown in Figure 1, consists of a shallow basin, soil or other medium to support the roots of vegetation, and a water control structure that maintains a shallow depth of water. The water surface is above the substrate. A VSB wetland consists of a sealed basin with a porous substrate of rock or gravel. The water level is designed to remain below the top of the substrate. In most of such VSB systems, the flow path is horizontal (VSB-H; Figure 2), although some systems use vertical flow paths (VSB-V; Figure 3). The bed of VSB wetlands can be either saturated or unsaturated with water. Typically, VSB wetlands are best suited for wastewaters with relatively low concentrations of solids given the hydraulic constraints 123 imposed by the substrate.

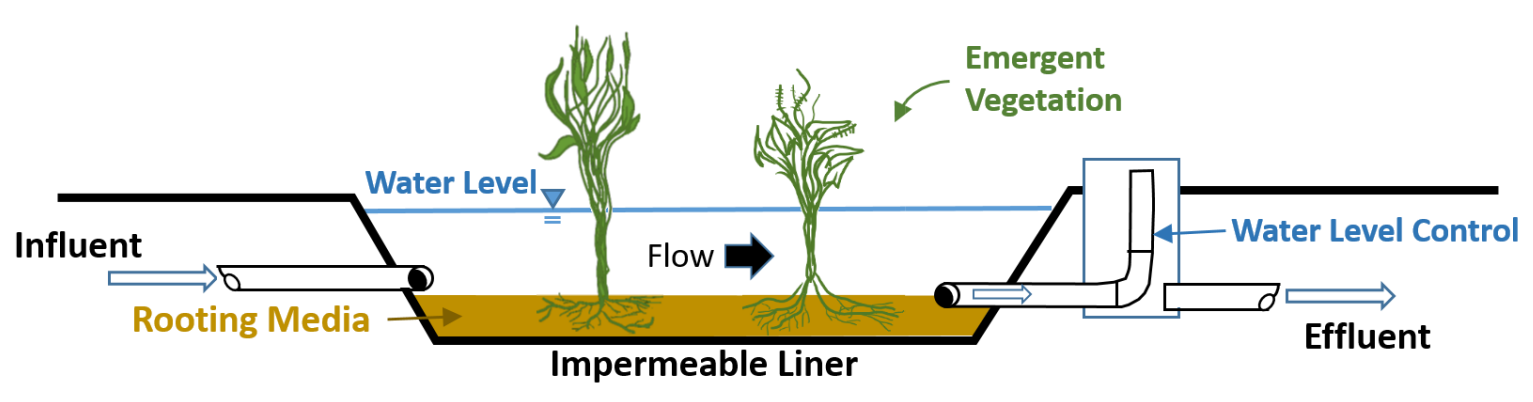

Figure 1 Schematic of a typical free water surface (FWS) constructed wetland 


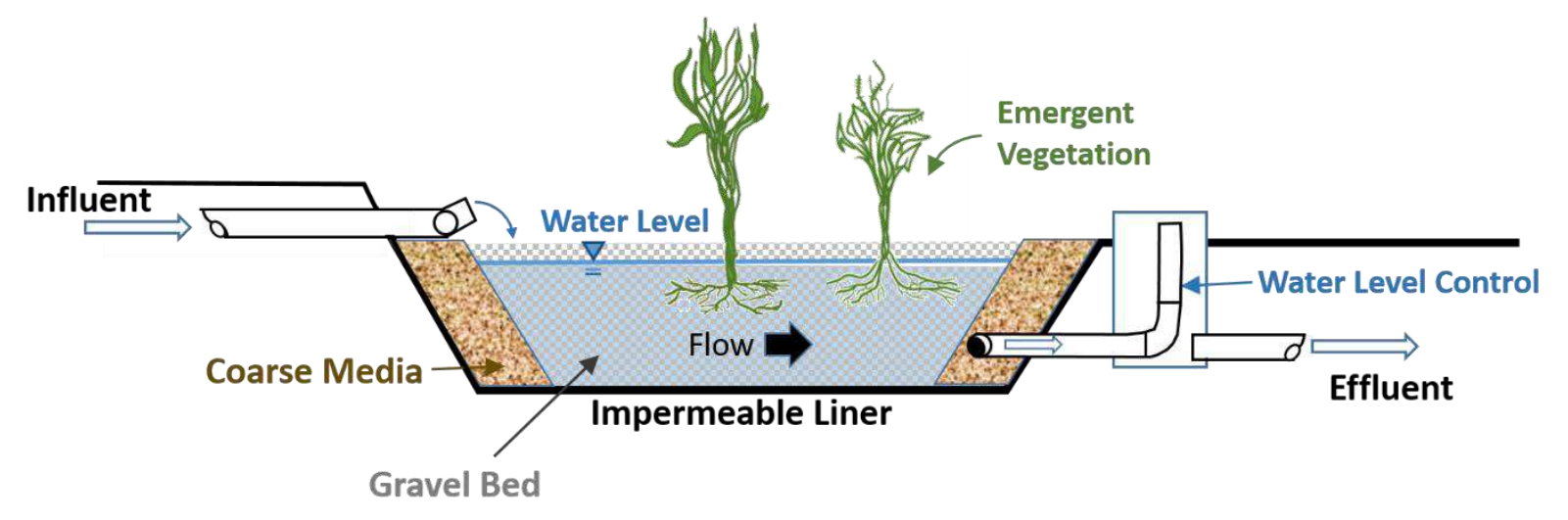

Figure $\mathbf{2}$ Schematic of a typical horizontal vegetated submerged bed (VSB-H) constructed wetland

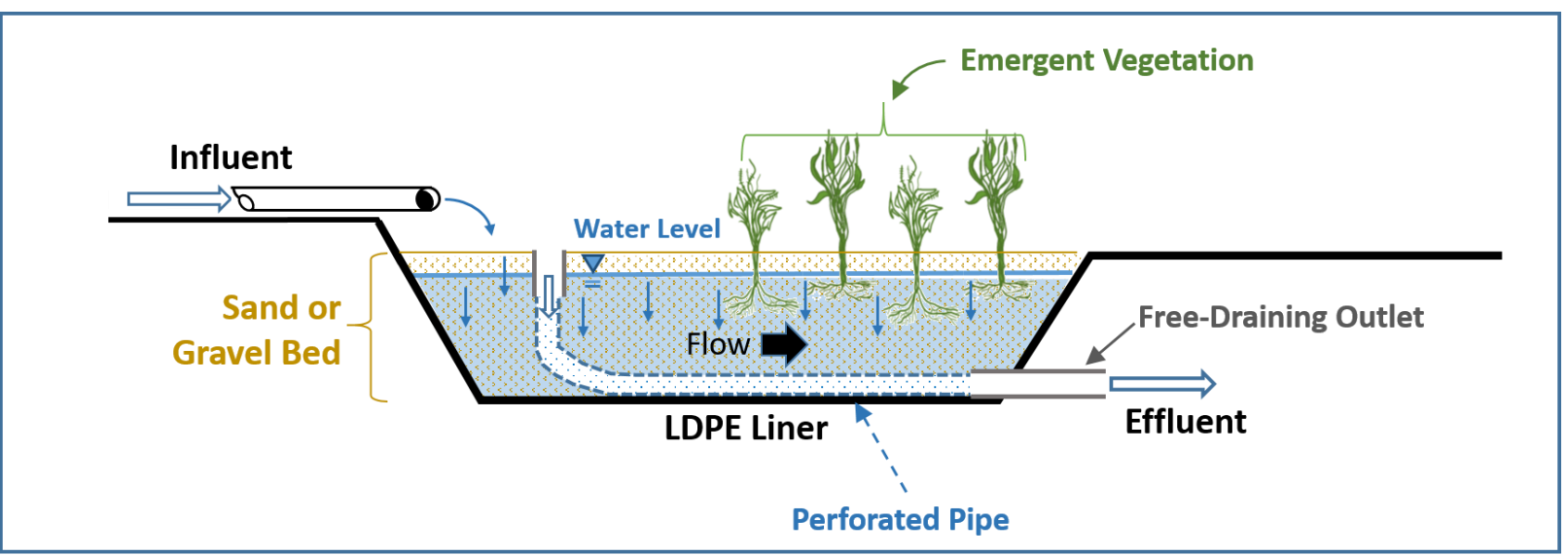

Figure 3 Schematic of a typical vertical vegetated submerged bed (VSB-V) constructed wetland

\subsection{WETLAND FEATURES}

The wetland processes that can enhance water quality generally fall into two categories: solids separation and constituent transformation. Solids separation includes settling, filtration, and sorption. Chemical transformations include microbial degradation, vegetative uptake, oxidation/reduction, and precipitation (USEPA, 2000). The role of various processes and the overall efficacy of the constructed wetland is governed by the choices made during design (i.e. the type of wetland, hydraulic characteristics, porous media selection, and plant selection), and of course the composition of the influent. For example, settling of particulate constituents is largely dependent on the hydraulic 
characteristics of the overlying water. Filtration (which is only of significance in VSB wetlands) will be largely driven by the choice of porous material. The choice of plants (rooted and/or algal) will have a large impact on the vegetative uptake of constituents, as different plants have differing uptake rates (Kadlec and Wallace, 2009). Microbial degradation is closely connected to the oxygen levels in the wetland (Bodelier and Dedysh, 2013), which in turn is affected by a wide variety of physical, chemical and biological characteristics.

\subsection{WETLAND PERFoRMANCE IN HOT AND ARID CLIMATES}

With respect to the performance of CWs in the hot and arid conditions of the Arabian Peninsula, the primary defining characteristics affecting wetlands are:

- $\quad$ High Temperature

- High Evapotranspiration

- Low Precipitation

The average annual temperatures in the Middle East reach $25^{\circ} \mathrm{C}$ and summer temperatures exceed $30^{\circ} \mathrm{C}$ (Stefanakis, 2020). Some regions of the Arabian Peninsula experience even more extreme conditions with average annual temperatures at sea level of $27^{\circ} \mathrm{C}$ and up to $45^{\circ} \mathrm{C}$ during summer months (Burt, 2017). Many biological processes, both macro- and micro-biotic, are enhanced under these higher temperatures compared to more temperate climates. Enhanced biological activity generally accelerate the growth and other transformative processes that are the main drivers of $\mathrm{CW}$ constituent removal in wastewater.

There can be challenges to $\mathrm{CW}$ operation in hot and arid climates due to the increased evapotranspiration (evaporation and plant transpiration). Transpiration generally will dominate the water loss (Kadlec, 2006). The combined water loss in these regions is often above $10 \%$, and can exceed $40 \%$ of the inflow. These losses will result in increased constituent values, which will generally degrade 
the quality of resulting CW effluent. The increased salinity values, if sufficiently high, may also have inhibitive effects on biological activity. CWs intended for arid climates are typically designed to minimize evapotranspirative losses, often by use of submerged (i.e. VSB) designs or minimizing the water exposed surface area. Selection of proper plant species is also essential as different species will have differing transpiration needs as well as differing salinity tolerances.

However, despite the challenges of increased transpiration, it can also have benefits. As plants absorb more water to cover their needs, more water is pulled down into the substrate, promoting nutrient and other constituent removal (Stefanakis, 2020).

Reduced precipitation in arid climates generally does not present much of a challenge for most CWs as long as the CW is provided with a continuous source of wastewater.

\subsection{PREVIOUS MODELING}

The complexity associated with wetlands can make them difficult to understand. For this reason, most of the available design guidelines are based on empirical observations or simple first-order decay models (Langergraber et al, 2008). While first-order models are of common use, they are mainly based on the influent characteristics, and the internal workings of the wetlands presume constancy of parameters. The result is simple first-order, irreversible pollutant reduction removal models that typically only work for particular wetlands under relatively steady conditions (Kadlec, 2000). Although useful, these types of models face difficulties in predicting wetland treatment efficiencies through different evolution stages of wetlands, over a long period of time, or when these wetlands may start to lose treatment capacity due to substrate saturation or decaying vegetation.

Mechanistic models are generally built bottom-up based on first principles. They are robust and general; however they require extensive data collection. Consequently, there have been few studies of 
constructed wetlands with sufficient data available to support the theory and to calibrate the models (USEPA, 2000). There has been recent advances in developing mechanistic wetland models, however the relatively few that have been developed in recent years have been somewhat limited by modeling only certain types of wetlands (Langergraber et al, 2008), certain types of constituents (Cancelli et al, 2019; Chu and Rediske, 2012), and/or certain processes (Mayo and Bigambo, 2005).

\subsection{SCOPE OF WORK}

The CWM is an expansion of the fate and transport models that were already available in Environmental Resource Management's (ERM's) Generalized Environmental Modeling System for Surfacewaters (GEMSS ${ }^{\circ}$ ). These models have been expanded based on information available from United States' Environmental Protection Agency (EPA) guidance document (USEPA, 2000) in addition to various other resources, as cited in relevant sections below. ERM and ExxonMobil Research Qatar (EMRQ) have developed several fate and transport models collaboratively (Kolluru et al., 2005; Adenekan et al., 2009; Febbo et al., 2012; Kolluru et al., 2003a; Kolluru et al. 2012,)for the region offshore of Ras Laffan Industrial City in the Arabian Gulf. These models, based on GEMSS, consists of several modules that compute the fate of various water quality and nutrient constituents. GEMSS ${ }^{\circledR}$ is an integrated system of three-dimensional hydrodynamic and transport modules embedded in a geographic information and environmental data system. Due to its vast capabilities, flexible design and previous use in Qatar, GEMSS was identified as the primary framework to be used to develop CWM.

GEMSS is designed in a modular fashion where hydrodynamic platform ("kernel") provides threedimensional surface (open water) flow fields from which the distribution of various constituents can be computed. The constituent transport and fate computations are grouped into modules. Prior to the development of the CWM, GEMSS ${ }^{\circledR}$ modules included those used for thermal analysis, water quality, sediment transport, particle tracking, oil and chemical spills, entrainment, and toxics. Therefore, the design of CWM required two enhancements: inclusion of sub-surface flows and inclusion of an 

subsection.

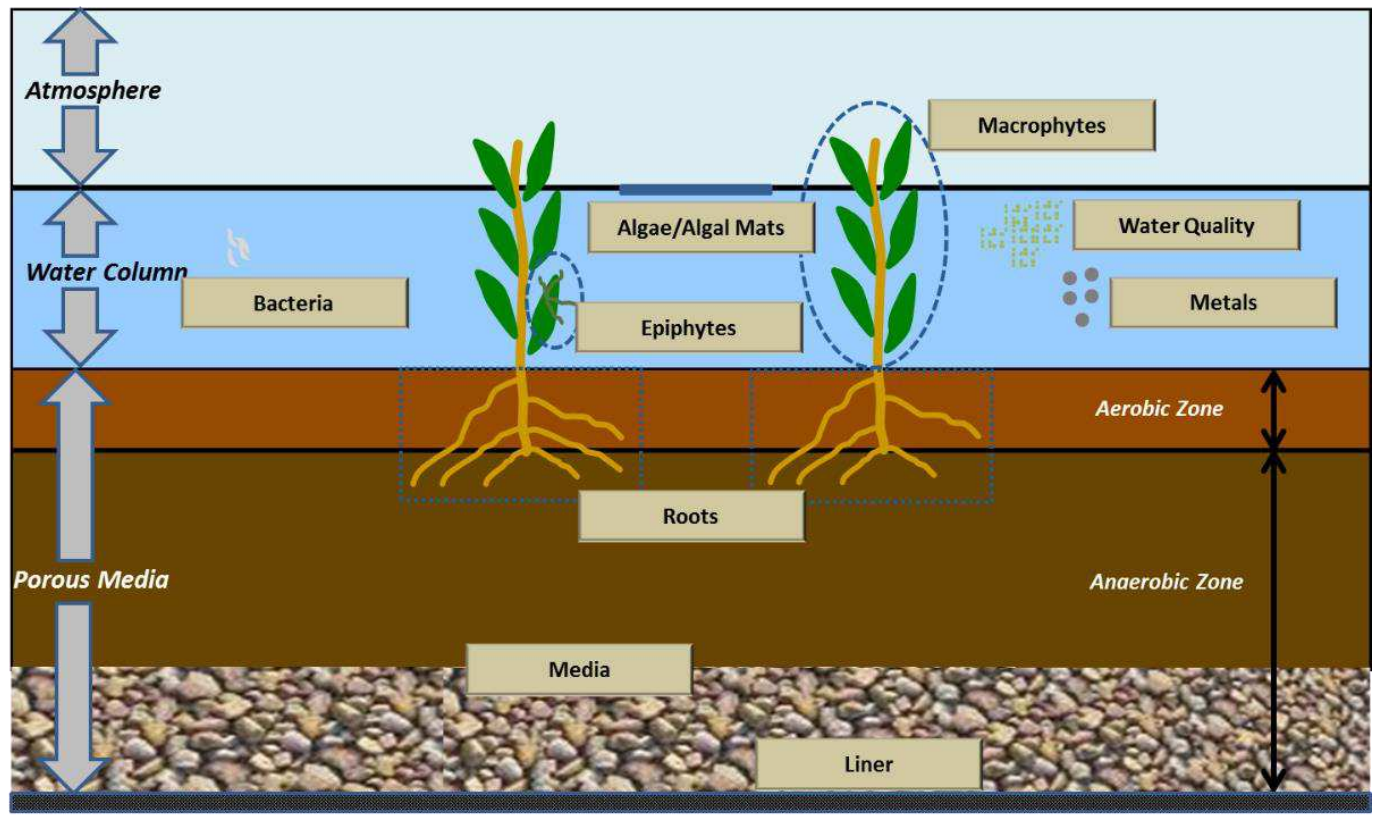

Figure 4 Simplified schematic showing various features within a constructed wetland

\section{METHODOLOGY}

The present section provides a brief theoretical background on the various concepts implemented during this model development. 


\subsection{MODEL DESIGN}

Throughout this paper terms are used to define these features and, therefore, it is important to establish a consistent terminology. Certain distinctions are being made to denote what is included as pre-defined (general properties set as default) versus what is user-defined (properties specifically defined by the user to represent engineered materials). These terms include:

- Zones: defined as process based
○ Water
- Aerobic sediments
- Anaerobic sediments

- Media: defined as physical state

○ Water

- Sediments

- Materials: defined as sediment (porous media) types

- Pre-defined (sand, gravel, clay, silt, etc.)

○ User-defined (engineered material, etc.)

- Regions: defined as materials/constituent specific

○ Materials

- Water - lack of any porous material

- Sediment - presence of various porous materials

- Vertically constant

- Constituents

- Water - presence of various plants, algae, bacteria, concentrations, etc.

- Sediment - presence of various roots, concentrations, etc.

- Vertically variable 


\subsection{THEORY}

Several basic assumptions regarding the zones, media, materials, and regions were made in the development of the CWM. These assumptions include:

- Two Media:

○ Water

- Sediments

- Three Zones:

○ Water

- Aerobic zone: dynamic location of aerobic/anaerobic interface

- Anaerobic zone

- Root "zone": part of the sediment zone

- Unlimited Materials

- Pre-defined or user-defined

- Unlimited Regions

$\circ \quad$ User-defined

\subsubsection{Transport}

A constructed wetland may have surfacewater overlying and flowing above porous or impermeable media. The porous media could be submergent (surfacewater above porous media) or emergent (no surfacewater above porous media). Accordingly, the wetland may also have subsurface flow through porous media. The CWM simulates the transport of water in both of these mediums under a combined interactive system.

\subsubsection{Surface Flows}

The movement of surface flows is modeled using the GEMSS hydrodynamic kernel. The theoretical basis of the kernel is the three-dimensional Generalized, Longitudinal-Lateral-Vertical Hydrodynamic and 
Transport (GLLVHT) model which was first presented in Edinger and Buchak (1980) and subsequently in Edinger and Buchak (1985). The GLLVHT computation has been peer reviewed and published (Edinger and Buchak, 1995; Edinger, et al., 1994 and 1997; Edinger and Kolluru, 1999). The hydrodynamic kernel is an extension of the well-known longitudinal-vertical transport model originally developed by Buchak and Edinger (1984) that forms the hydrodynamic and transport basis of the Corps of Engineers' water quality model CE-QUAL-W2 (U. S. Army Engineer Waterways Experiment Station, 1986). Improvements to the transport scheme, construction of the constituent modules, incorporation of supporting software tools, GIS interoperability, visualization tools, graphical user interface (GUI), and post-processors have been developed by Kolluru et al. (1998; 1999; 2003a; 2003b) and by Prakash and Kolluru (2006).

\subsubsection{Vegetative Resistance}

The vegetation in CWM is implemented through the use of two different existing modules within GEMSS: macrophytes and epiphytes. Macrophytes are the rooted vegetation and epiphytes are plants attached to the macrophytes. In heavily vegetated waterbodies such as wetlands, vegetation can restrict flow through the surfacewater through both friction and the reduction of cross-sectional area. These flow restrictions were implemented through the use of free surfacewater frictional forces, and are based on the total plant area normal to the direction of flow $\sum A_{i}$ which is estimated using biomass to surface area ratios from Sher-Kaul et al. (1995) and surface area to volume ratios from Sand-Jensen and Borum (1991). The drag coefficient $C_{d}$ is a calibration parameter that is of the order of 1.0 for vegetation. Vegetative drag results in an effective Manning's friction factor $n$, as calculated by Petryk and Bosmajian (1975) and shown in:

$$
n=n_{b} \sqrt{1+\frac{C_{d} \sum A_{i}}{2 g V} \frac{1}{n_{b}^{2}} R^{4 / 3}}
$$

where: 
$\mathrm{n}=$ Effective Manning's friction factor

$\mathrm{n}_{\mathrm{b}} \quad=\quad$ Manning's friction factor due to bed friction only []

$\mathrm{C}_{\mathrm{d}} \quad=$ Drag coefficient []

$\mathrm{R} \quad=$ Hydraulic radius [L]

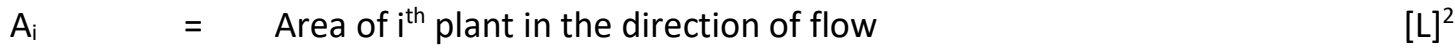

$\begin{array}{llll}\mathrm{V} & =\text { Cell volume } & {[\mathrm{L}]^{3}}\end{array}$

$\mathrm{L} \quad=\quad$ Cell length in direction of flow $\quad$ [L]

$\mathrm{g}=$ Gravitational acceleration $\left.[\mathrm{L}]^{[\mathrm{T}}\right]^{-2}$

The reduced cross-sectional area is simply achieved by applying an effective porosity of the surfacewater:

$$
\varphi=\frac{V-V_{m}}{V}
$$

where:

$\phi \quad=\quad$ Water porosity due to vegetation (macrophytes only)

$\mathrm{V}_{\mathrm{m}} \quad=\quad$ Cell volume occupied by macrophytes

\subsubsection{Sub-Surface Flows}

As noted earlier, the main kernel of GEMSS includes the surface flows. A separate module was developed and integrated with the main surface flow kernel to provide flow connectivity between surface and sub-surface flows. The sub-surface flow module is called GEMSS-GWM (GroundWater Module). This linkage is dynamic, with real time information shared between the free surfacewater elevation and piezometric head within the porous media.

In a groundwater (or porous media) system, the mass balance for the three-dimensional movement of constant density ground water through a porous material can be shown to be represented by the Richards Equation (written in term of local pressure head):

$$
S_{S} \frac{\partial h}{\partial t}=\vec{\nabla} \circ(k \vec{\nabla} h)+W
$$

where: 


$\begin{array}{llll}S_{S} & = & \text { Specific storage, the change in saturation per unit head } & {[\mathrm{L}]^{-1}} \\ h & = & \text { Local pressure head } & {[\mathrm{L}]} \\ k & = & \text { Hydraulic conductivity } & {[\mathrm{L}][\mathrm{T}]^{-1}} \\ W & = & \text { Volumetric flux of sources and/or sinks per unit volume } & {[\mathrm{T}]^{-1}} \\ t & = & \text { Time } & {[\mathrm{T}]}\end{array}$

The specific storage can be rewritten as shown:

$$
S_{S}=\frac{\phi}{V_{v}} \frac{\partial V_{w}}{\partial h}
$$

where:

$\begin{array}{llll}V_{w} & = & \text { Water volume } & {[\mathrm{L}]^{3}} \\ V_{v} & = & \text { Void volume, volume potentially filled by water or air } & {[\mathrm{L}]^{3}} \\ \phi & = & \text { Porosity }\left(\mathrm{V}_{\mathfrak{w}} \mathcal{N}_{\mathrm{w}}\right) & {[]}\end{array}$

The sub-surface transport is completely specified by the Richards Equation, transport and/or head at the boundaries of the modeled region, and initial head throughout the region. For finite-difference models such as GEMSS, these equations need to be discretized into a solvable system of equations. The method used for discretization is based on a scheme adopted in MODFLOW (Harbaugh, 2005).

GEMSS-GWM performs the temporal calculations using a combined implicit and explicit formulation. An implicit formulation is more numerically stable; however, it requires longer computational times. Due to the complexity of calculations in the CWM, the hybrid system is utilized. The explicit formulation is used in the horizontal direction and the implicit formulation is used in the vertical direction.

The GEMSS-GWM module of CWM includes conditions possible within the porous media such as partial saturation and wetting/drying (water level moving up and down leaving parts of the porous media completely dry). For the sake of brevity, details on the approach used for partially saturated flow is not described here, but can be obtained from MODFLOW-2005 documentation (Harbaugh, 2005). The 
approach taken for wetting/drying is to have a dry cell convert to wet when the computed head in the cell directly below exceeds a bottom elevation of the dry cell.

\section{Evapotranspiration}

An important mechanism for water loss is the evapotranspiration. This mechanism was included to simulate water losses through plant transpiration and direct evaporation by removing appropriate water from the groundwater zone. The approach is based on a few assumptions as follows:

- When the water table is at or above a specified elevation, termed the "ET surface", evapotranspiration loss from the water table occurs at a maximum rate specified by the user;

- When the depth of the water table below the ET surface elevation exceeds a specified interval, termed the "extinction depth" or "cutoff depth", evapotranspiration from the water table ceases; and

- Between these limits, evapotranspiration from the water table varies linearly with water-table elevation.

\subsubsection{Constituent Fate}

In consultation with the various industries in Qatar, ERM and EMRQ identified a list of constituents that would be typically present in the wastewater, including those that have been generally been found in produced water resulting from natural gas extraction. These constituents were designated for inclusion in the CWM. These constituents were further evaluated from the perspective of their role in nutrient/vegetative interaction and their role in eutrophication/water quality (Cerco and Cole, 1995; Cole and Wells, 2013; Pelletier and Chapra, 2008; Thomas and Scott, 2004; USEPA, 2006; USEPA, 2013). The CWM utilizes the existing GEMSS water quality module (GEMSS-WQM) that includes the various nutrient cycles and associated water quality parameters such as dissolved oxygen and algae. The fate processes applicable to the nutrients (carbon, nitrogen and phosphorus) have been well-studied (Cole and Wells, 2013; Chapra, 1997; Thomann and Mueller, 1987; USEPA, 2006). GEMSS-WQM (and CWM) is based on the concepts discussed and published by USEPA (USEPA, 2000) for these nutrients. The 
GEMSS-WQM module addresses most of the constituents related to the dissolved and particulate forms in the water column.

The fate processes of constituents that were not originally included in GEMSS were then added as part of the CWM development. In addition to the expansion of the existing modules and implementation of additional nutrient cycle processes, various fate processes for the non-nutrient constituents (metals, $\mathrm{pH}$, sulfide, calcium, oil and grease) were implemented. The fate processes related to these constituents are specific to the choice of plants and media. Therefore, the assumptions and basis for the formulas used for model calculations are based on generic but user-definable concepts. Processes such as ionization, dissolution, adsorption, settlement and speciation are also calculated in the model. All processes governed by formulas with theoretical or experimentally derived parameters, are initially set to default values based on valid assumptions, but are also available as user inputs through the model GUI.

The table below contains the complete list of constituents and associated processes included in the CWM.

Table 1 List of constituents and associated fate processes

\begin{tabular}{|l|l|}
\hline Constituent & Processes \\
\hline Algae & Excretion, respiration, photosynthesis, mortality \\
\hline Macrophytes & Respiration, photosynthesis, mortality \\
\hline Epiphytes & Excretion, respiration, photosynthesis, mortality \\
\hline Organic Matter: Dissolved & Excretion, decay \\
\hline Organic Matter: Particulate & Decay, mortality, sorption, settlings, burial \\
\hline
\end{tabular}




\begin{tabular}{|c|c|}
\hline Constituent & Processes \\
\hline Dissolved Oxygen & Respiration, photosynthesis, reaeration, decay \\
\hline Dissolved Inorganic Carbon & Respiration, photosynthesis, reaeration, decay \\
\hline Organic Nitrogen: Dissolved & Excretion, decay \\
\hline Organic Nitrogen: Particulate & Decay, mortality, settlings, burial \\
\hline Organic Phosphorus: Dissolved & Excretion, decay \\
\hline Organic Phosphorus: Particulate & Decay, mortality, settlings, burial \\
\hline Ammonium & Respiration, photosynthesis, decay, nitrification \\
\hline Nitrate/Nitrite & Photosynthesis, denitrification, nitrification \\
\hline Phosphate & Respiration, photosynthesis, decay \\
\hline Bacteria/Pathogens & Mortality, settling, burial \\
\hline Cyanide & Volatilization, decay, sorption, settling, burial \\
\hline Phenol & Volatilization, decay, sorption, settling, burial \\
\hline Oil \& Grease & Volatilization, decay \\
\hline Sulfide & Uptake, oxidation, reduction, sorption, settlings, burial \\
\hline Sulfate & Uptake, oxidation, reduction, sorption, settlings, burial \\
\hline $\mathrm{pH}$ & $\begin{array}{l}\text { Various reactions, see section Error! Reference source not } \\
\text { found. }\end{array}$ \\
\hline
\end{tabular}




\begin{tabular}{|c|c|}
\hline Constituent & Processes \\
\hline Alkalinity & $\begin{array}{l}\text { Various reactions, see section Error! Reference source not } \\
\text { found. }\end{array}$ \\
\hline Inorganic Solids & Settling, burial \\
\hline Metals: Aluminum & \multirow{13}{*}{$\begin{array}{l}\text { Respiration, excretion, mortality, vegetative uptake, sorption, } \\
\text { precipitation, settling, burial, volatilization (Mercury only) }\end{array}$} \\
\hline Metals: Arsenic & \\
\hline Metals: Barium & \\
\hline Metals: Cadmium & \\
\hline Metals: Chromium & \\
\hline Metals: Cobalt & \\
\hline Metals: Copper & \\
\hline Metals: Iron & \\
\hline Metals: Lead & \\
\hline Metals: Manganese & \\
\hline Metals: Mercury & \\
\hline Metals: Nickel & \\
\hline Metals: Zinc & \\
\hline
\end{tabular}



concentration or sink for decrease in algal concentration.

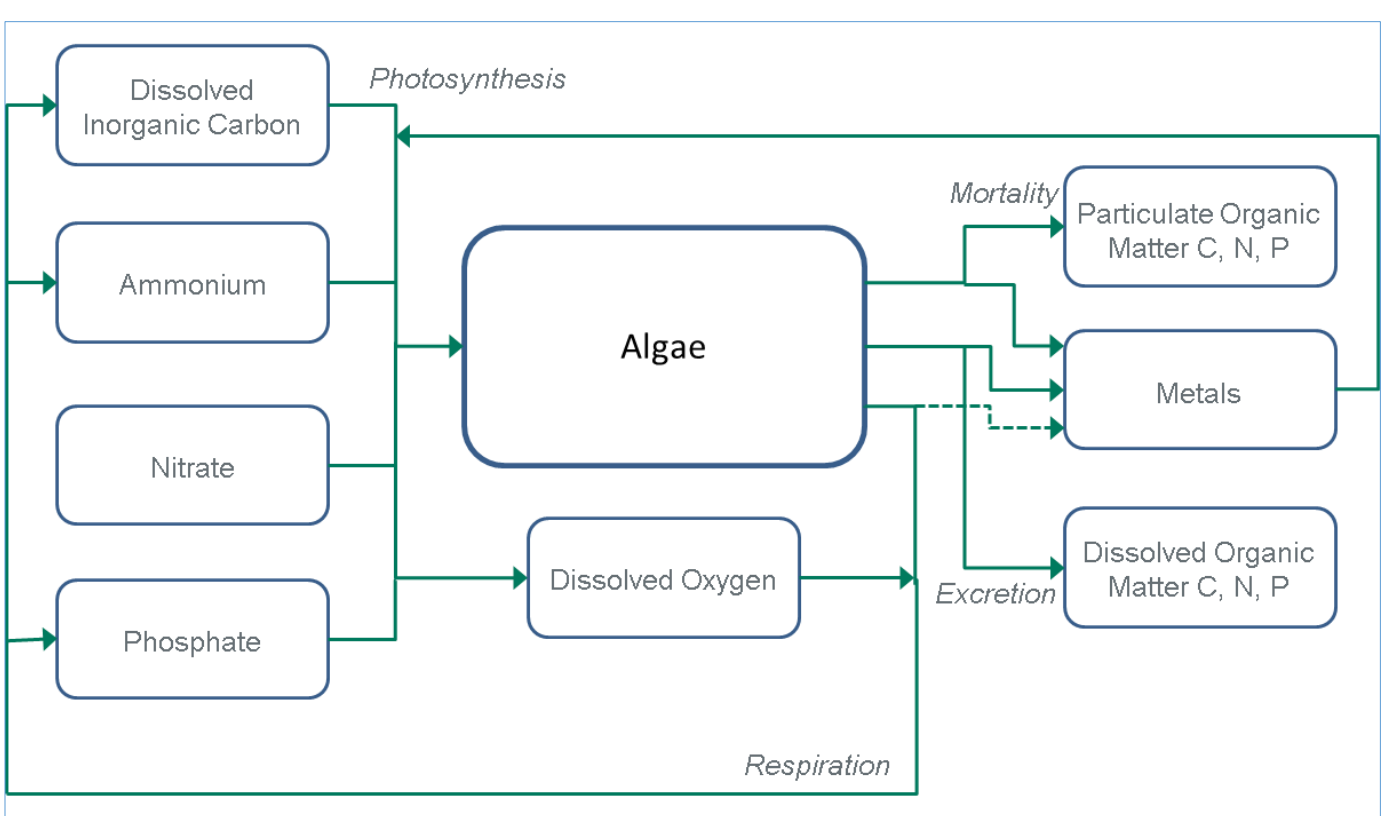
selected and representative constituents are discussed below. Formulations related to other constituents follow similar approach and are process based, as shown below:

\subsubsection{Algae}

The overall fate processes related to algal groups (algae and algal mats) are shown in Figure 5. CWM allows any number of algal groups that can be defined by modifying the various rates related to the individual processes. Each of these processes serves as either a source for increase in algal

\section{Figure 5 Fate processes associated with various algal groups}

The overall source/sink mass balance equation based on Figure 5 is shown as:

$S_{a}=K_{a g} A L G-K_{a r} A L G-K_{a e} A L G-K_{a m} A L G$

where

For the sake of brevity, detailed formulations of the various fate and processes are shown only for

$\mathrm{S}_{\mathrm{a}} \quad=\quad$ Algal source/sink in Carbon (C) 
ALG $=$ Algal Concentration in C

$[\mathrm{M}][\mathrm{L}]^{-3}$

$\mathrm{K}_{\mathrm{ag}}=$ Algal Growth Rate

$[\mathrm{T}]^{-1}$

$\mathrm{K}_{\mathrm{ar}}=$ Algal Respiration Rate

$[\mathrm{T}]^{-1}$

$\mathrm{K}_{\mathrm{ae}}=$ Algal Excretion Rate

$[\mathrm{T}]^{-1}$

$\mathrm{K}_{\mathrm{am}}=$ Algal Mortality Rate

\subsubsection{Dissolved Oxygen}

The overall fate processes related to dissolved oxygen (DO) are shown in Figure 6. Each of these processes serves as either a source for DO concentrations or sink for DO concentrations.

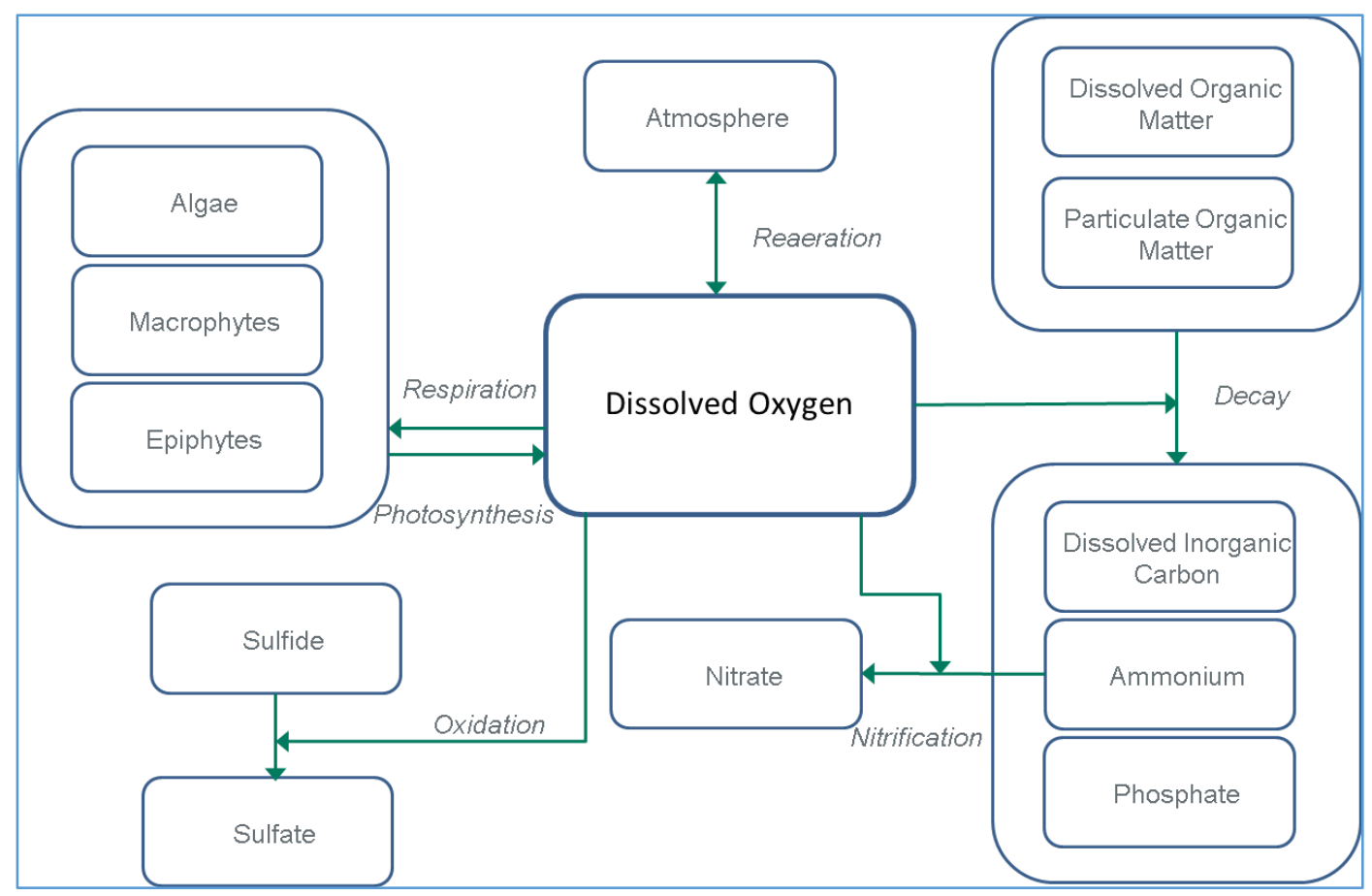

Figure 6 Fate processes for dissolved oxygen

The overall source/sink equation based on Figure 6 is shown as:

$$
\begin{gathered}
S_{D O}=\left(\frac{M W_{O 2}}{M W_{C}}\right)\left\{K_{a g} A L G+K_{e g} E P I+K_{m g} M A C-K_{a r} A L G-K_{e r} E P I-K_{m r} M A C-K_{D O M} D O C\right. \\
\left.-K_{P O M} P O C\right\}+\frac{K l_{O 2}}{h}\left(D O_{s}-D O\right)-\frac{3 M W_{O 2}}{2 M W_{N}} K_{n i t} N H 4-2 M W_{O 2} O^{S^{2-} \cdot S_{O_{4}}{ }^{2-}}
\end{gathered}
$$

where: 


\begin{tabular}{|c|c|c|c|}
\hline$S_{D O}$ & $=$ & Dissolved Oxygen source/sink & {$[\mathrm{M}][\mathrm{L}]^{-3}[\mathrm{~T}]^{-1}$} \\
\hline DOC & $=$ & Dissolved Organic Carbon Concentration in C & {$[\mathrm{M}][\mathrm{L}]^{-3}$} \\
\hline POC & $=$ & Particulate Organic Carbon Concentration in C & {$[\mathrm{M}][\mathrm{L}]^{-3}$} \\
\hline EPI & $=$ & Epiphyte Concentration in C & {$[\mathrm{M}][\mathrm{L}]^{-3}$} \\
\hline MAC & $=$ & Macrophyte Concentration in C & {$[\mathrm{M}][\mathrm{L}]^{-3}$} \\
\hline DO & $=$ & Dissolved Oxygen Concentration & {$[\mathrm{M}][\mathrm{L}]^{-3}$} \\
\hline $\mathrm{NH} 4$ & $=$ & Ammonium Concentration in Nitrogen $(\mathrm{N})$ & {$[\mathrm{M}][\mathrm{L}]^{-3}$} \\
\hline$K_{\text {DOM }}$ & $=$ & Dissolved Organic Matter Decay Rate & {$[T]^{-1}$} \\
\hline K & $=$ & Particulate Organic Matter Decay Rate & {$[T]^{-1}$} \\
\hline $\mathrm{K}_{\mathrm{eg}}$ & $=$ & Epiphyte Growth Rate & {$[\mathrm{T}]^{-1}$} \\
\hline $\mathrm{K}_{\mathrm{mg}}$ & $=$ & Macrophyte Growth Rate & {$[T]^{-1}$} \\
\hline $\mathrm{K}_{\mathrm{er}}$ & $=$ & Epiphyte Respiration Rate & {$[T]^{-1}$} \\
\hline $\mathrm{K}_{\mathrm{mr}}$ & $=$ & Macrophyte Respiration Rate & {$[T]^{-1}$} \\
\hline $\mathrm{Kl}_{\mathrm{O} 2}$ & $=$ & DO Reaeration Rate & {$[\mathrm{L}][\mathrm{T}]^{-1}$} \\
\hline h & $=$ & Depth & {$[\mathrm{L}]$} \\
\hline $\mathrm{DO}_{\mathrm{s}}$ & $=$ & Saturation DO Concentration & {$[\mathrm{M}][\mathrm{L}]^{-3}$} \\
\hline$K_{\text {nit }}$ & $=$ & Nitrification Rate & {$[T]^{-1}$} \\
\hline $\mathrm{O}$ S.SO4 & $=$ & Oxidation Rate of Sulfide to Sulfate & {$[\mathrm{L}][\mathrm{T}]^{-1}$} \\
\hline $\mathrm{MW}_{\mathrm{O} 2}$ & $=$ & Molecular Weight of Oxygen $\left(\mathrm{O}_{2}\right)$ & {$[\mathrm{g} / \mathrm{mol}]$} \\
\hline $\mathrm{MW}_{\mathrm{C}}$ & $=$ & Molecular Weight of Carbon & {$[\mathrm{g} / \mathrm{mol}]$} \\
\hline $\mathrm{MW}_{\mathrm{N}}$ & $=$ & Molecular Weight of Nitrogen & [g/mol] \\
\hline
\end{tabular}

\subsubsection{Phosphate}

The overall fate processes related to phosphate (PO4) are shown in Figure 7. Each of these processes

serves as either a source for phosphate concentrations or sink for phosphate concentrations.

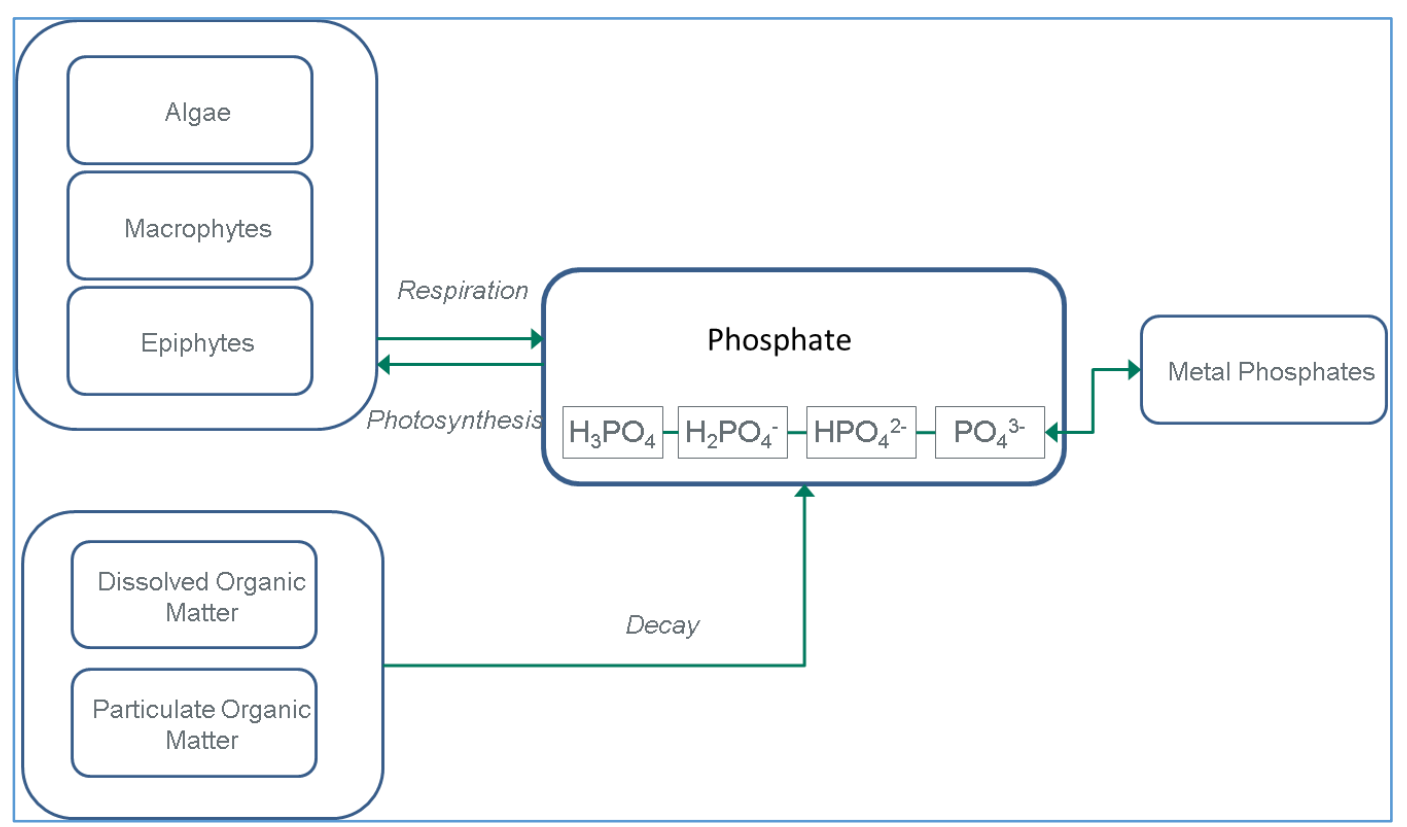

Figure 7 Fate processes for phosphate 
The overall source/sink equation based on Figure 7 is shown as:

$$
\begin{gathered}
S_{P O 4}=K_{D O M} D O P+K_{P O M} P O P-\alpha_{a p c} K_{a g} A L G-\alpha_{e p c} K_{e g} E P I-\alpha_{m p c} K_{m g} M A C+\alpha_{a p c} K_{a r} A L G \\
+\alpha_{e p c} K_{e r} E P I+\alpha_{m p c} K_{m r} M A C-R_{M \cdot P O 4}
\end{gathered}
$$

where:

$\begin{array}{llll}\mathrm{S}_{\mathrm{PO} 4} & = & \text { Phosphate source/sink in Phosphorus }(\mathrm{P}) & {[\mathrm{M}][\mathrm{L}]^{-3}[\mathrm{~T}]^{-1}} \\ \mathrm{DOP} & = & \text { Dissolved Organic Phosphorus Concentration in } \mathrm{P} & {[\mathrm{M}][\mathrm{L}]^{-3}} \\ \mathrm{POP} & = & \text { Dissolved Organic Phosphorus Concentration in P } & {[\mathrm{M}][\mathrm{L}]^{-3}} \\ \mathrm{PO} 4 & = & \text { Phosphate Concentration in P } & {[\mathrm{M}][\mathrm{L}]^{-3}} \\ \alpha_{\mathrm{apc}} & = & \text { Algal Phosphorus to Carbon Ratio } & {[\mathrm{g}-\mathrm{P} / \mathrm{g}-\mathrm{C}]} \\ \alpha_{\mathrm{epc}} & = & \text { Epiphyte Phosphorus to Carbon Ratio } & {[\mathrm{g}-\mathrm{P} / \mathrm{g}-\mathrm{C}]} \\ \alpha_{\mathrm{mpc}} & = & \text { Macrophyte Phosphorus to Carbon Ratio } & {[\mathrm{g}-\mathrm{P} / \mathrm{g}-\mathrm{C}]} \\ \mathrm{R}_{\mathrm{M} \cdot \mathrm{PO} 4} & = & \text { Metal Phosphate Precipitation/Dissolution Rate } & {\left[\mathrm{g}-\mathrm{P} / \mathrm{m}^{3}-\mathrm{s}\right]}\end{array}$

\subsubsection{Metals}

The CWM models the fate of thirteen (13) metals. These metals experience a varied range of fate processes including vegetative (algae, macrophytes and epiphytes) uptake and sorption to organic matter. Additionally, the precipitates of these metals settle or dissolve. These three fate processes are common to all metals and are discussed in the following sub-sections separately. For full details of each metal, including additional processes specific to individual metals, the reader is directed to the complete CWM documentation available by request to the authors.

Vegetative Metal Uptake/Release

The net vegetative metal uptake rate [mol/L-s] (sink) for each metal is given by:

$$
U_{V E G}^{M}=\frac{r_{a}^{M} K_{a g} A L G+r_{e}^{M} K_{e g} E P I+r_{m}^{M} K_{m g} M A C}{M W^{M}}
$$

where:

$$
\mathrm{U}_{\mathrm{VEG}}^{\mathrm{M}}=\text { Metal Vegetative Uptake Rate } \quad[\mathrm{mol}][\mathrm{L}]^{-3}[\mathrm{~T}]^{-1}
$$




$\begin{array}{llll}\mathrm{M} & = & \text { Metal Constituent } & \\ \mathrm{r}_{\mathrm{a}}{ }^{\mathrm{M}} & = & \text { Algae Uptake Constant for Metal M } & {[\mathrm{L}]\left[\mathrm{L}^{-1}\right.} \\ \mathrm{r}_{\mathrm{e}}{ }^{\mathrm{M}} & = & \text { Epiphyte Uptake Constant for Metal M } & {[\mathrm{L}][\mathrm{L}]^{-1}} \\ \mathrm{r}_{\mathrm{m}}{ }^{\mathrm{M}} & = & \text { Macrophyte Uptake Constant for Metal M } & {[\mathrm{L}][\mathrm{L}]^{-1}} \\ \mathrm{MW}^{\mathrm{M}} & = & \text { Molecular Weight of Metal M } & {[\mathrm{g} / \mathrm{mol}]}\end{array}$

For each metal, the vegetative metal release rate $[\mathrm{mol} / \mathrm{L}-\mathrm{s}]$ due to respiration, excretion, and mortality is given by:

$$
R_{V E G}^{M}=\left(K_{a r}+K_{a e}+K_{a m}\right) C_{a}^{M}+\left(K_{e r}+K_{e e}+K_{e m}\right) C_{e}^{M}+\left(K_{m r}+K_{m m}\right) C_{m}^{M}
$$

412 where:

$\begin{array}{llll}\mathrm{R}^{{ }^{M}}{ }_{\text {VEG }} & = & \text { Metal Vegetative Release Rate } & {[\mathrm{mol}][\mathrm{L}]^{-3}[\mathrm{~T}]^{-1}} \\ \mathrm{C}_{\mathrm{a}}{ }^{\mathrm{M}} & = & \text { Concentration of Metal Constituent in Algae } & {[\mathrm{mol} / \mathrm{L}]} \\ \mathrm{C}_{\mathrm{e}}{ }^{\mathrm{M}} & = & \text { Concentration of Metal Constituent in Epiphytes } & {[\mathrm{mol} / \mathrm{L}]} \\ \mathrm{C}_{\mathrm{m}}{ }^{\mathrm{M}} & = & \text { Concentration of Metal Constituent in Macrophytes } & {[\mathrm{mol} / \mathrm{L}]} \\ \mathrm{K}_{\mathrm{ee}} & = & \text { Epiphyte Excretion Rate } & {[\mathrm{T}]^{-1}} \\ \mathrm{~K}_{\mathrm{em}} & = & \text { Epiphyte Mortality Rate } & {[\mathrm{T}]^{-1}} \\ \mathrm{~K}_{\mathrm{mm}} & = & \text { Macrophyte Mortality Rate } & {[\mathrm{T}]^{-1}}\end{array}$

For each metal, the freely dissolved metal is assumed to be in equilibrium with the metal sorbed to organic matter. The dissolved and particulate fractions, respectively, are given by:

$$
\begin{aligned}
& f_{d}^{M}=\frac{\phi}{\phi+K d^{M} P O C} \\
& f_{p}^{M}=\frac{K d^{M} P O C}{\phi+K d^{M} P O C}
\end{aligned}
$$

where:

$\begin{array}{llll}f^{M}{ }_{d} & = & \text { Metal Dissolved Fraction } & {[]} \\ f^{M} M_{p} & = & \text { Metal POC Particulate Fraction } & {[]} \\ \mathrm{K}_{d}{ }^{\mathrm{M}} & = & \text { Organic Carbon Partition Coefficient for M } & {[\mathrm{L}]^{3}[\mathrm{M}]^{-1}} \\ \Phi & = & \text { Porosity } & {[]}\end{array}$


The rate of precipitation/dissolution [mol/L-s] of each of the metal precipitate can be given by:

$$
P^{M \cdot p}=K^{M \cdot p}\left(C_{d}^{M}-C^{M *}\right)
$$

where:

$\begin{array}{llll}\mathrm{P}^{\mathrm{M}^{*} \mathrm{p}} & = & \text { Rate of Precipitation/Dissolution of Metal Precipitate } & {[\mathrm{mol}][\mathrm{L}]^{-3}[\mathrm{~T}]^{-1}} \\ \mathrm{M} \cdot \mathrm{p} & = & \text { Metal Precipitate Constituent } & \\ \mathrm{K}^{\mathrm{M} \cdot \mathrm{p}} & = & \text { Rate Constant for Constituent, } \mathrm{M} \cdot \mathrm{p} & {[\mathrm{T}]^{-1}} \\ \mathrm{C}_{\mathrm{d}}{ }^{\mathrm{M}} & = & \text { Freely Dissolved Concentration of Constituent, } \mathrm{M} & {[\mathrm{mol} / \mathrm{L}]} \\ \mathrm{C}^{\mathrm{M}^{*}} & = & \text { Solubility of Constituent, } \mathrm{M} & {[\mathrm{mol} / \mathrm{L}]}\end{array}$

The solubility of the constituent, $M$ is based on the solubility product as shown:

$$
K s p^{M \cdot p}=\prod_{i} C_{i}^{*}
$$

where:

$$
\begin{array}{lllr}
\mathrm{K}_{\mathrm{sp}}{ }^{\mathrm{M}^{*} \mathrm{p}} & =\text { Metal Precipitate Solubility } & \text { [mol/L] } \\
\mathrm{i} & =\text { Precipitate lons } & {[\mathrm{mol} / \mathrm{L}]} \\
\mathrm{C}_{\mathrm{i}}^{*} & = & \text { Solubility of lon } \mathrm{i} &
\end{array}
$$

\subsubsection{Constituent Transport}

The fate processes discussed in the previous section provide the sink and source for each individual constituent modeled within CWM. The transport equations referenced and discussed earlier provide the flow velocities for each discretized model cell. These two combine to form the generalized constituent transport equation shown below. 


$$
\frac{\partial C}{\partial t}+u \frac{\partial C}{\partial x}+v \frac{\partial C}{\partial y}+w \frac{\partial C}{\partial z}=D_{x} \frac{\partial^{2} C}{\partial x^{2}}+D_{y} \frac{\partial^{2} C}{\partial y^{2}}+D_{z} \frac{\partial^{2} C}{\partial z^{2}}+S
$$

where:

$$
\begin{array}{lll}
C & = & \text { Concentration of a constituent } \\
u, v, w & = & \text { Velocities in } \mathrm{x}, \mathrm{y} \text { and } \mathrm{z} \text { directions } \\
D_{x}, D_{y}, D_{z} & = & \text { Diffusivities in } \mathrm{x}, \mathrm{y} \text { and } \mathrm{z} \text { directions } \\
S & = & \text { Net source/sink term }
\end{array}
$$

This constituent transport equation can be solved within CWM using a variety of schemes (Upwind, QUICKEST and QUICKEST+ULTIMATE), and explicitly or implicitly (Prakash and Kolluru, 2006).

\section{$4 \quad$ RESULTS AND DISCUSSION}

There are currently insufficient data to conduct an actual model performance evaluation as a result we applied the model in an illustrative fashion. This application aims to demonstrate some key model features. There are extensive efforts underway to calibrate the model using data from the biggest CW in the Middle East, Nimr Project. In 2011, Petroleum Development Oman in collaboration with Bauer Nimr LLC commissioned the construction of a constructed wetland, one of the largest industrial constructed wetland systems in the world, to manage produced water from the Nimr oilfields in Oman. This wetland has been operating since as part of the Nimr Water Treatment Plant (Nimr WTP) and has demonstrated the utility of natural treatment process to achieve multiple significant environmental benefits as well as substantial savings in operating costs compared to conventional methods of disposal (Stefanakis et al, 2018).

\subsection{EFFECTS OF HOT AND ARID CONDITIONS ON MODEL PERFORMANCE}

\subsubsection{Temperature}

Generally higher temperatures are conducive to wetland performance. Higher temperatures typically result in higher biologic activity (vegetative and microbial), and these are reflected in the rate 

need for proper selection of plant species conducive to local climates.

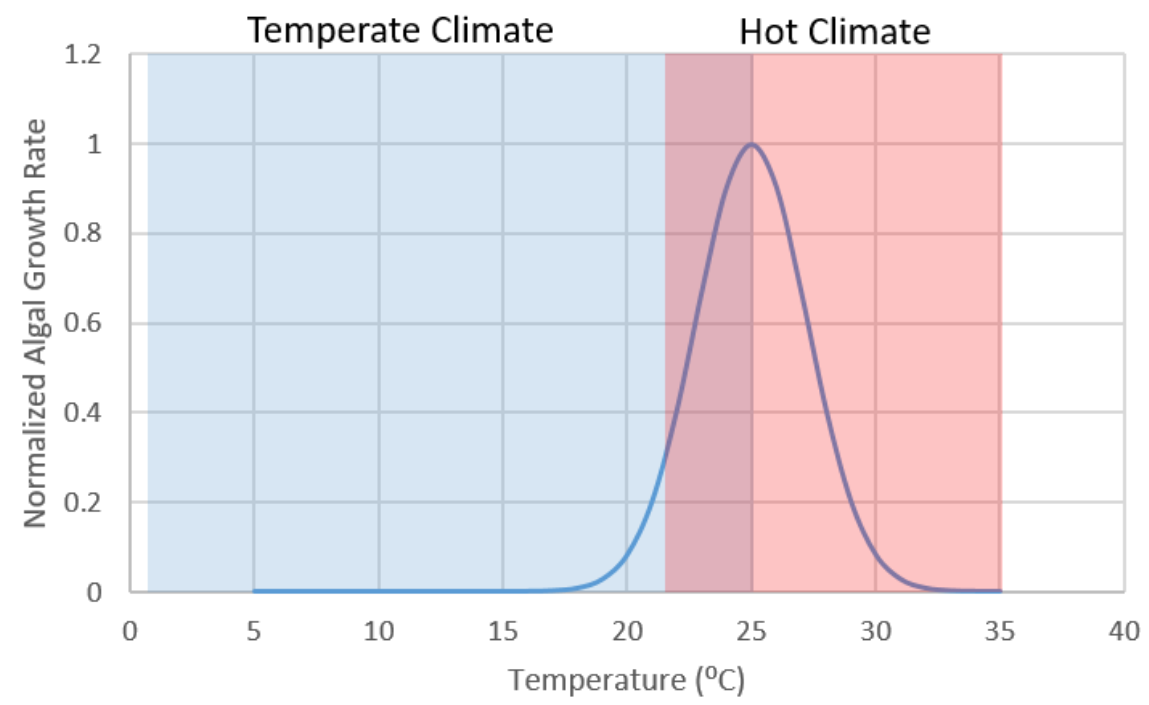

Figure 8 Example Algal Growth Temperature Response 


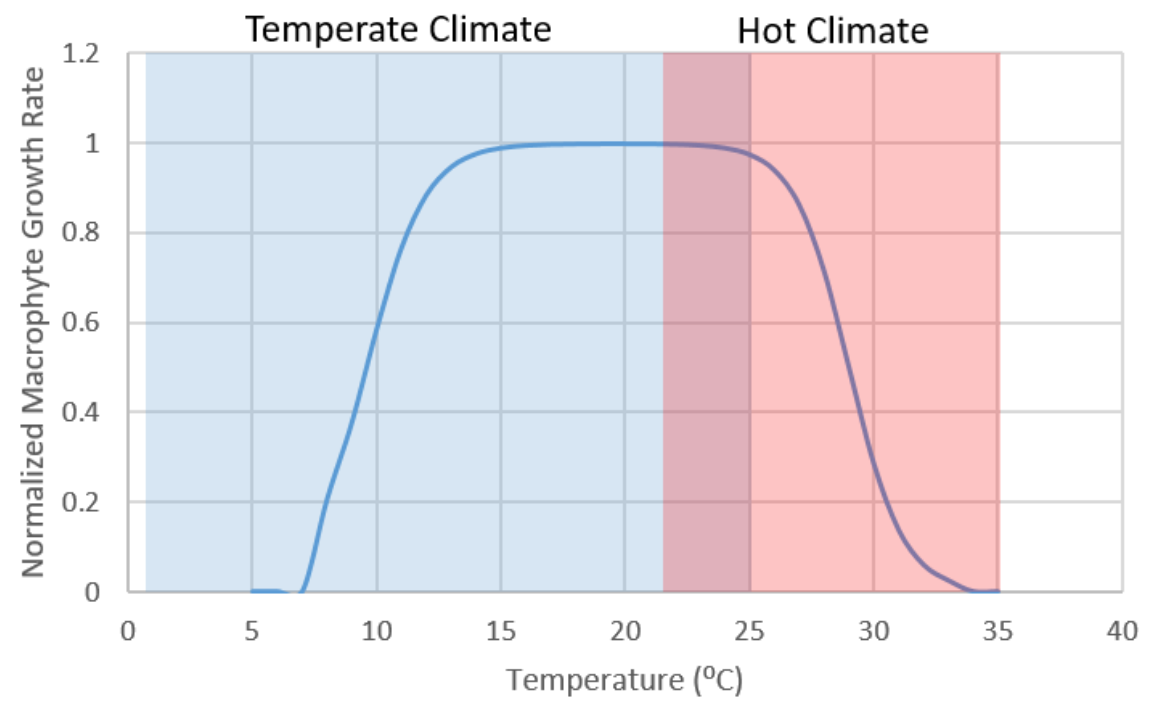

\section{Figure 9 Example Macrophyte Growth Temperature Response}

Microbial activity is also strongly dependent on temperature. However unlike algal and macrophyte activity, higher temperature nearly always favors higher activity. Some of the processes mediated by bacteria, such as organic matter degradation, nitrification, and denitrification, are shown in example Figure 10 and Figure 11. As can be seen from these figures, these wetland processes are significantly enhanced in hot climates, by factors of 2-3x. 


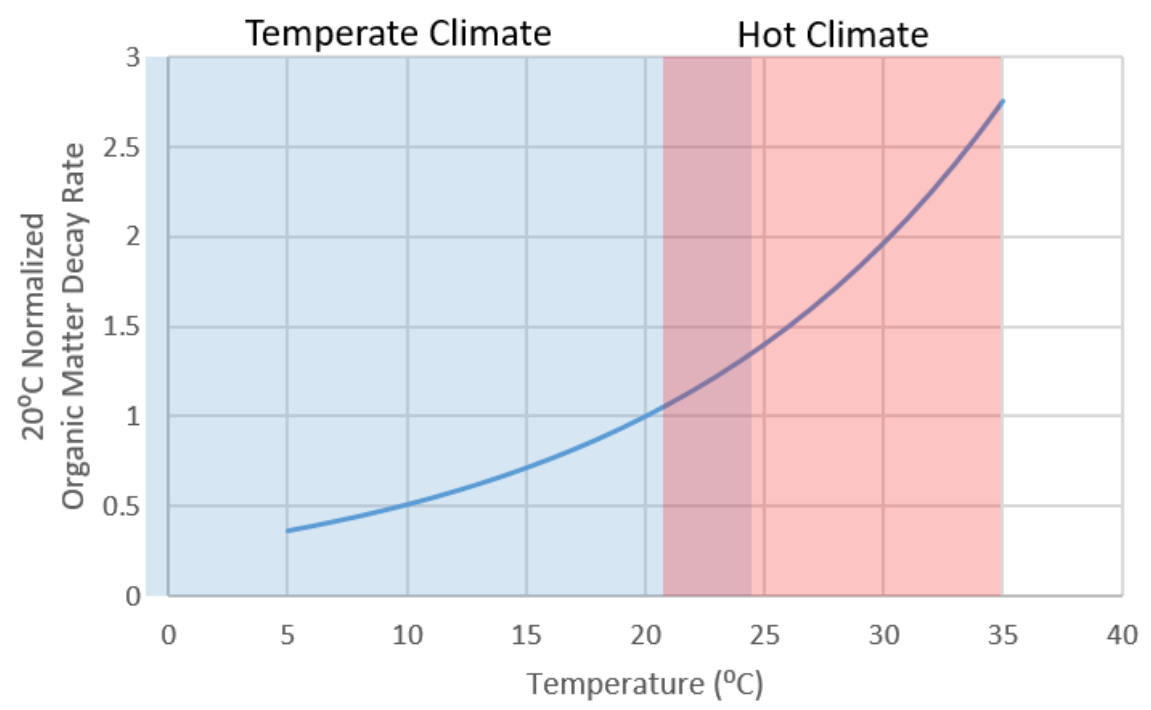

Figure 10 Example Organic Decay Temperature Response

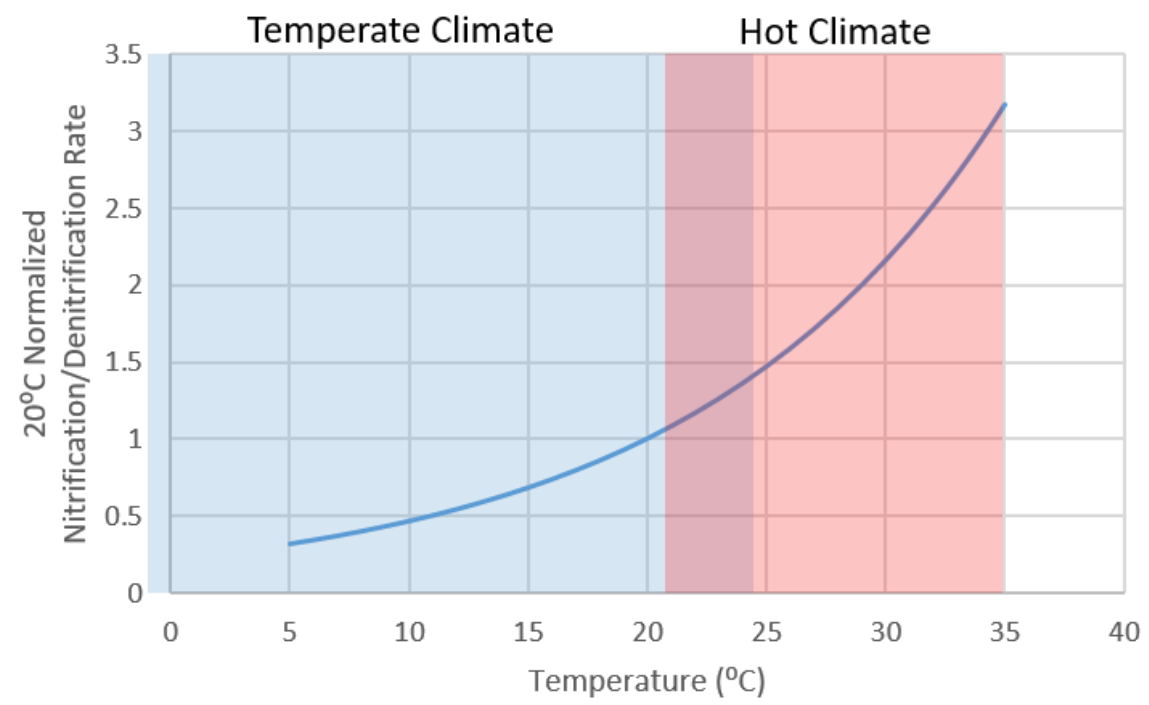

Figure 11 Example Nitrification and Denitrification Temperature Response

Another process significantly enhanced at higher temperatures is volatilization. While not an important process for nutrient or metals removal, volatilization can be important for the removal of volatile organic compounds, such as phenol, in FWS wetlands. An example of this the temperature effect on 
volatilization is shown in Figure 12, which shows $20-30 \%$ increases in this wetland process in hot climates.

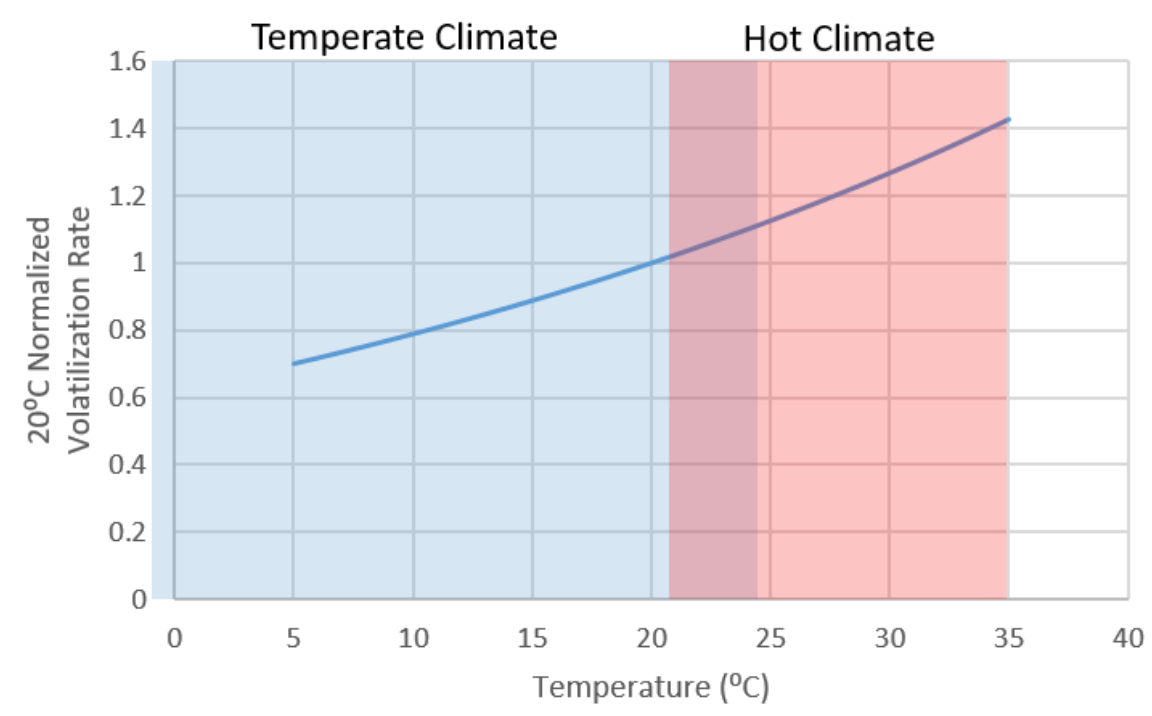

Figure 12 Example Volatilization Temperature Response

\subsubsection{Evapotranspiration}

Water loss through evapotranspiration in hot and arid climates will generally hinder CW performance as the constituents in the water become more concentrated, making it more difficult to meet water reuse standards. Another effect of this concentration of constituents is the increase in salinity, which can retard algal growth. Figure 13 shows an example of the inhibitive effect of salinity on algal growth. To put the effect into perspective, for a FWS in an arid region that experiences $20 \%$ water loss (and a resulting salinity increase of $20 \%$ ), algal growth may be inhibited by $5-25 \%$. 


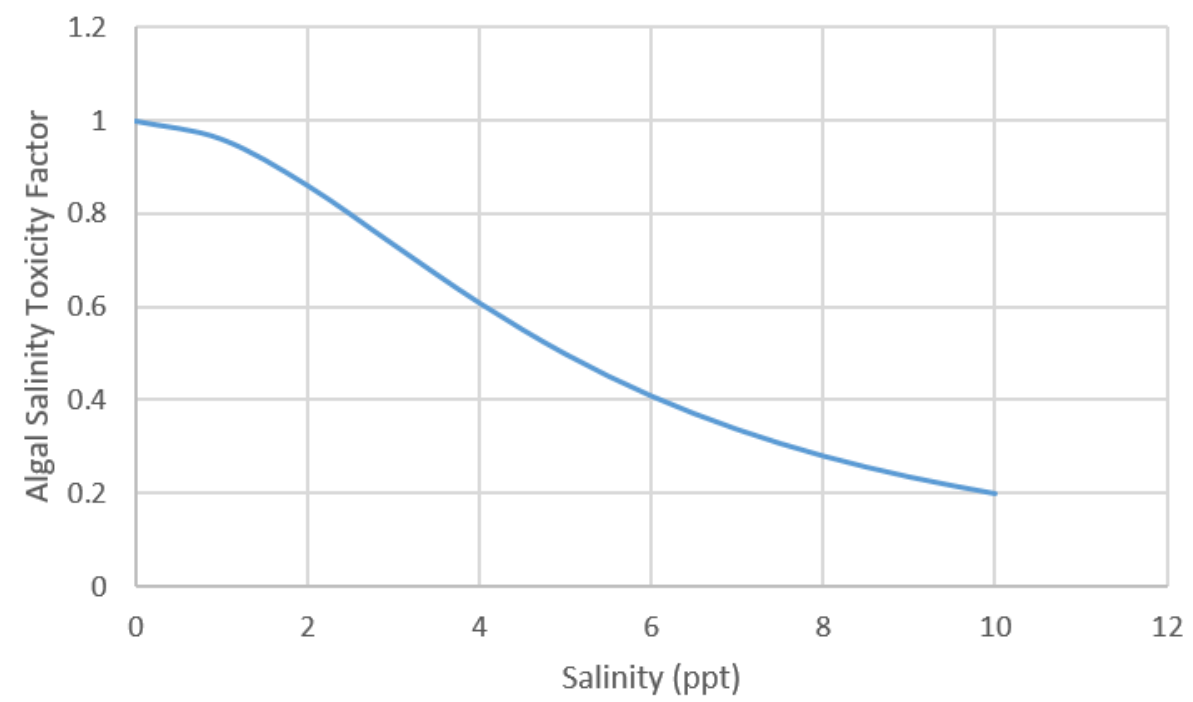

Figure 13 Example Algal Growth Salinity Response

\section{MODEL LIMITATIONS}

The model development discussed in this report and the resulting model, CWM, is to be considered "in progress". Development of the CWM is a stepwise, research-based modeling exercise. During the present stage, the model framework and algorithms have been developed and made functional. Subsequently, model formulations will need to be validated, model limitations analyzed and addressed, and model refinements made, before and during use in full-scale operations and design. As such, it is recognized that the present stage of model development is "experimental", and future refinements of the model are anticipated. ERM and EMRQ are currently in the process of validating the CWM through its application to an existing wetland, as discussed later.

\section{CONCLUSIONS AND FUTURE WORK}

In 2020, a field data program was designed for the Nimr WTP with the purpose of providing data to allow simulation of the associated wetland through CWM. After collection and analysis of this data has been conducted, this data will be used to parameterize CWM inputs and begin calibration of the water 
quality and vegetative components of the CWM to reproduce the observable data trends. The objective of the application of CWM to Nimr WTP is to demonstrate the utility of the model to simulate constructed wetlands at other locations to assist managers in the design of similar systems to achieve suitable treatment of produced water for beneficial reuse. The results of these simulations will consist of a follow-up paper documenting the application to the Nimr WTP and the utility of the CWM to further the goal of constructed wetland design.

A mechanistic model was developed to evaluate the fate and transport of constituents throughout a constructed wetland. The model is completely generalized in order to allow the user to simulate any type of wetland, with any configuration, and any selection of material and plants. The model simulates the majority of physical, chemical, and biological processes that occur in wetlands and are responsible for the removal of constituents. The model was initially configured to simulate nutrients, metals, and a wide variety of other water quality parameters, but is also flexible enough to allow the simulation of any number of other constituents such as hydrophobic contaminants. The model relies on a large body of existing literature to formulate each process.

At this time, the model has not been validated with a compete simulation of an actual wetland, however a data collection program has been designed for the Nimr WTP constructed wetland in order to provide a robust dataset to allow model testing, calibration, and validation. It is anticipated that the results of this study and the corresponding model application will be published in subsequent paper(s) once complete.

Upon evaluation of the accuracy and challenges of the model to reproduce an actual existing functional wetland, the expectation is that the model can be used during the design phase of future constructed wetlands as a tool to allow water treatment engineers to test various sizes, modes, configurations and materials to arrive at optimal designs for their particular treatment needs. 


\section{$7 \quad$ FUNDING}

The authors thank EMRQ for financial support of this study. The authors declare that they have no known competing financial interests or personal relationships that could have appeared to influence the work reported in this paper.

\section{CONFLICTS OF INTEREST}

There is no conflict of interest.

\section{DATA AVAILABILITY}

Not applicable.

10 CODE AVAILABILITY

The model will be part of the GEMSS model that is shared in limited capacity to universities, research agencies, regulators and clients. Limited source code can be shared under separate sharing agreement.

\section{AUTHOR CONTRIBUTIONS}

Prakash, Kolluru, Zahakos, and Saeed designed the study. Kolluru, Prakash, and Zahakos developed the model. Zahakos wrote the article. Saeed, Prakash, and Prigent commented on draft versions of the article. Varghese and Prigent assisted with data and logistics. All authors have approved the final article.

\section{DISCLAIMER}

The authors alone are responsible for the views expressed in this publication and they do not necessarily represent the views, decisions or policies of the ERM, EMRQ, or Bauer Resources.

\section{ACKNOWLEDGMENTS}

This work was financially supported by EMRQ. Mohamad Al-Sulaiti, Christopher Warren, and Josh Butler (ExxonMobil) are gratefully acknowledged for their initiation and support of model development. Liang Kuang and Alexander Hoogland (ERM) are acknowledged for their contributions to model development. 
14 REFERENCES

Adenekan, A.E., Kolluru, V.S., Smith, J.P., 2009. Transport and Fate of Chlorination By-Products

Associated with Cooling Water Discharges. Proceedings of the $1^{\text {st }}$ Annual Gas Processing Symposium, 1-

13.

Bodelier P.L.E., Dedysh, S.N., 2013. Microbiology of wetlands. Frontiers in Microbiology, vol. 4 79. 5 Apr. 2013.

Brix, H., 1993. Wastewater Treatment in Constructed Wetlands: System Design, Removal Processes, and Treatment Performance. Constructed Wetlands for Water Quality Improvement, G.A. Moshiri (ed.), CRC Press, Inc.

Buchak, E. M., Edinger, J.E., 1984. Generalized, Longitudinal-Vertical Hydrodynamics and Transport: Development, Programming and Applications. Prepared for U.S. Army Corps of Engineers Waterways Experiment Station, Vicksburg, MS, Contract No. DACW39-84-M-1636. Prepared by J. E. Edinger Associates, Wayne, PA. Document No. 84-18-R. June.

Burt, J.A., Ben-Hamadou, R., Abdel-Moati, M.A.R., Fanning, L., Kaitibie, S., Al-Jamali, F., Range, P., Saeed, S., Warren, C.S., 2017. Improving management of future coastal development in Qatar through ecosystem-based management approaches. Ocean \& Coastal Management 148, 171-181.

Cancelli, A.M., Gobas, F.A.P.C., Wang, Q., Kelly, B.C., 2019. Development and evaluation of a mechanistic model to assess the fate and removal efficiency of hydrophobic organic contaminants in horizontal subsurface flow treatment wetlands. Water Research 151, 183-192.

Cerco, C.F., Cole, T., 1995. User's guide to the CE-QUAL-ICM three-dimensional eutrophication model, Release version 1.0. Technical Report EL-95-15. US Army Corps of Engineers Water Experiment Station, Vicksburg, MS.

Chapra, S. C., 1997. Surface water-quality modeling. McGraw-Hill, Boston, MA. 
Chu, X., Rediske, R., 2012. Modeling Metal and Sediment Transport in a Stream-Wetland System. ASCE Journal of Environmental Engineering 138, 152-163.

Cole, T.M., Wells, S.A., 2013. CE-QUAL-W2: a two-dimensional, laterally-averaged, hydrodynamic and water quality model, Version 3.71.

Edinger, J. E., Buchak, E. M., 1980. Numerical Hydrodynamics of Estuaries in Estuarine and Wetland Processes with Emphasis on Modeling, P. Hamilton and K. B. Macdonald, eds., Plenum Press, New York, NY, 115-146.

Edinger, J. E., Buchak, E. M., 1985. Numerical Waterbody Dynamics and Small Computers. Proceedings of ASCE 1985 Hydraulic Division Specialty Conference on Hydraulics and Hydrology in the Small Computer Age. American Society of Civil Engineers, Lake Buena Vista, FL. Aug. 13-16.

Edinger, J. E., Buchak, E. M., McGurk, M. D., 1994. Analyzing Larval Distributions Using Hydrodynamic and Transport Modelling. Estuarine and Coastal Modeling III. American Society of Civil Engineers, New York, NY.

Edinger, J. E., Buchak, E. M., 1995. Numerical Intermediate and Far Field Dilution Modelling. Journal Water, Air and Soil Pollution 83, 147-160.

Edinger J.E., Wu, J., Buchak, E.M., 1997. Hydrodynamic and Hydrothermal Analyses of the Once-through Cooling Water System at Hudson Generating Station. Prepared for Public Service Electric and Gas. Prepared by J. E. Edinger Associates, Inc., June.

Edinger, J. E., Kolluru, V. S., 1999. Implementation of Vertical Acceleration and Dispersion Terms in an Otherwise Hydrostatically Approximated Three-Dimensional Model. Proceedings of the $6^{\text {th }}$ International Conference on Estuarine and Coastal Modeling, Spaulding, M.L, H. L. Butler (eds.), 1019-1034. 
Eger P., Wagner, J., 2002. The use of wetlands to remove nickel from mine drainage - Is perpetual treatment really possible? Presented at the 2002 National Meeting of the American Society of Mining and Reclamation, Lexington, KY, June 9-13.

Febbo E., Kolluru, V.S., Prakash, S., Adenekan, A., 2012. Numerical Modeling of Thermal Plume and Residual Chlorine Fate in Coastal Waters of the Arabian Gulf. Presented at the SPE/APPEA International Conference on Health, Safety, and Environment in Oil and Gas Exploration and Production, Perth, Western Australia. 11-13 September.

Harbaugh, A.W., 2005. MODFLOW-2005, The U.S. Geological Survey Modular Ground-Water Modelthe ground water flow process. U.S. Geological Survey Techniques and Methods 6-A16.

IDEM, 1997. Constructed Wetland Wastewater Treatment Facilities Guidance. Indianapolis, IN.

ITRC, 2003. Technical and Regulatory Guidance Document for Constructed Treatment Wetlands. Prepared by The Interstate Technology \& Regulatory Council Wetlands Team.

James B.B., Bogart, R., 1989. Wastewater treatment/disposal in a combined marsh and forest system provides for wildlife habitat and recreational use. In: Constructed Wetlands for Wastewater Treatment: Municipal, Industrial, and Agricultural, D.A. Hammer (ed.), Lewis Publishers, Chelsea, MI, 597-605.

Kadlec R.H., 2000. The inadequacy of first-order treatment wetland models. Ecological Engineering 15, 105-119.

Kadlec R.H., 2006. Water temperature and evapotranspiration in surface flow wetlands in hot arid climate. Ecological Engineering 26 (4), 328-340.

Kadlec R.H., Wallace, S.D., 2009. Treatment Wetlands, second ed. Taylor \& Francis Group, Boca Raton, FL. 
Kolluru, V. S., Buchak, E. M., Edinger, J. E., 1998. Integrated Model to Simulate the Transport and Fate of Mine Tailings in Deep Waters. Proceedings of the Tailings and Mine Waste '98 Conference, Fort Collins, CO, January 26-29.

Kolluru, V. S., Buchak, E. M., Wu, J., 1999. Use of Membrane Boundaries to Simulate Fixed and Floating Structures in GLLVHT. Proceedings of the 6th International Conference on Estuarine and Coastal Modeling, M.L. Spaulding, H.L. Butler (eds.), 485-500.

Kolluru, V. S., Edinger, J. E., Buchak, E. M., Brinkmann, P.E., 2003a. Hydrodynamic Modeling of Coastal LNG Cooling Water Discharge. Journal of Energy Engineering, 129 (1), 16-31.

Kolluru, V.S., Fichera, M.J., 2003b. Development and Application of Combined 1-D and 3-D Modeling System for TMDL Studies. Proceedings of the $8^{\text {th }}$ International Conference on Estuarine and Coastal Modeling, American Society of Civil Engineers, 108-127.

Kolluru, V.S., Buchak, E.M., Edinger, J.E., Brinkmann, P.E., 2005. Three-Dimensional Thermal Modeling of the RasGas Cooling Water Outfall.

Kolluru, V.S., Prakash, S., Febbo, E., 2012. Modeling the Fate and Transport of Residual Chlorine and Chlorine By-Products (CBP) in Coastal Waters of the Arabian Gulf. The $6^{\text {th }}$ International Conference on Environmental Science and Technology, Houston, TX, June 25-29.

Knight R.L., Kadlec, R.H., Ohlendorf, H.M., 1999. The use of treatment wetlands for petroleum industry effluents. Environmental Science and Technology 33 (7), 973-980.

Langergraber, G., Giraldib, D., Menac, J., Meyerd, D., Penae, M., Toscanof, A., Brovellig, A., Korkusuza, E.A., 2008. Recent developments in numerical modelling of subsurface flow constructed wetlands. Science of the Total Environment, Elsevier, September. 
Marshall, D.E., 1971. Characteristics of Spartina marsh which is receiving treated municipal sewage wastes. In: Studies of Marine Estuarine Ecosystems Developing with Treated Sewage Wastes. Annual report for 1969-1970, H.T. Odum, A. Chestnut (eds.), University of North Carolina Institute of Marine Sciences, Morehead City, NC, 313-363.

Mayo, A.W., Bigambo, T., 2005. Nitrogen transformation in horizontal sub- surface flow constructed wetlands: I. Model development. Physics and Chemistry of the Earth 30.

Mitsch, W.J., Gosselink, J.G., 2007. Wetlands, fourth ed. John Wiley \& Sons, Inc., Hoboken, NJ.

Moshiri G.A., 1993. Constructed Wetlands for Water Quality Improvement. CRC Press, Inc.

Odum, H.T., 1985. Self-organization of estuarine ecosystems in marine ponds receiving treated sewage.

Data from experimental pond studies at Morehead City, North Carolina, 1968-1972, Data report, University of North Carolina Sea Grant Publication \#UNC-SG-85-04.

Prakash, S., Kolluru, V.S., 2006. Implementation of higher order transport schemes with explicit and implicit formulations in a 3-D hydrodynamic and transport model. Published in the $7^{\text {th }}$ International Conference on Hydroscience and Engineering (ICHE 2006), Philadelphia, PA, September 10-13.

Petryk, S., Bosmajian, G., 1975. Analysis of flow through vegetation. Journal of the Hydraulics Division 101 (7), 871-884.

Pelletier, G., Chapra, S., 2008. QUAL2Kw user manual (Version 5.1). Department of Ecology, Olympia, WA.

RREL, 1993. Handbook for Constructed Wetlands Receiving Acid Mine Drainage. Risk Reduction Engineering Laboratory Office of Research and Development, Cincinnati, OH. 
Sand-Jensen, K., Borum, J., 1991. Interactions among phytoplankton, periphyton, and macrophytes in temperate freshwaters and estuaries. Aquatic Botany 41 (1-3), 137-175.

Scholz M., 2006. Wetland Systems to Control Urban Runoff. Elsevier Science. Amsterdam, Netherlands.

Sher-Kaul, S., Oertli, B., Castella, E. and Lachavanne, J., 1995. Relationship between biomass and surface area of six submerged aquatic plant species. Aquatic Botany 51, 147-154.

Spangler F.L., Sloey, W.E., Fetter, C.W.Jr., 1976. Wastewater treatment by natural and artificial marshes. EPA 600/2-76-207, U.S. EPA Office of Water, Ada, OK.

Stefanakis, A.I., Prigent S., Breuer, R., 2018. Integrated Produced Water Management in a Desert Oilfield Using Wetland Technology and Innovative Reuse Practices. Constructed Wetlands for Industrial Wastewater Treatment, first ed., A.I. Stefanakis (ed.), John Wiley \& Sons Ltd.

Stefanakis, A.I., 2020. Constructed Wetlands for Sustainable Wastewater Treatment in Hot and Arid Climates: Opportunities, Challenges and Case Studies in the Middle East. Water 12, 1665.

Sudarsan, J.S., Annadurai, R., Mukhopadhyay, M., Chakraborty, P., Nithiyanantham S., 2018. Domestic wastewater treatment using constructed wetland: an efficient and alternative way. Sustainable Water Resource Management 4, 781-787.

Tchobanoglous,G., 1993. Constructed Wetlands and Aquatic Plant Systems: Research, Design, Operational, and Monitoring Issues. Constructed Wetlands for Water Quality Improvement, G.A. Moshiri (ed.), CRC Press, Inc.

Thomann, R.V., Mueller, J.A., 1987. Principles of Surface Water Quality Modeling and Control. Harper \& Row, New York, NY. 
Thomas, M.C., Scott, A.W., 2004. CE-QUAL-W2: A two-dimensional, laterally averaged, hydrodynamic and water quality model, Version 3.2 User Manual. U.S. Army Engineer Waterways Experiment Station, Vicksburg, MS, 22-50.

UN-HABITAT, 2008. Constructed Wetlands Manual. UN-HABITAT Water for Asian Cities Programme, Nepal, Kathmandu.

U.S. Army Engineer Waterways Experiment Station, Environmental Laboratory, Hydraulics Laboratory, 1986. CE-QUAL-W2: A Numerical Two-Dimensional, Laterally Averaged Model of Hydrodynamics and Water Quality; User's Manual. Instruction Report E-86-5, Final Report. Prepared for Department of the Army, U.S. Army Corps of Engineers, Washington, DC, August.

USEPA, 2000. Constructed wetlands treatment of municipal wastewaters. United States Environmental Protection Agency, Office of Research and Development, Cincinnati, OH. EPA/625/R-99/010.

USEPA. Wool, T. A., Ambrose, R. B., Martin, J. L., Comer, E.A., 2006. Water quality analysis simulation program (WASP) User's Manual, Version, 6.

USEPA, 2013. Water Quality Analysis Simulation Program (WASP) Version 8.32. https://www.epa.gov/ceam/water-quality-analysis-simulation-program-wasp, last accessed December $14,2020$.

Vymazal J., 2009. The use of constructed wetland with horizontal sub-flow for various types of wastewater. Ecological Engineering 35 (1), 1-17.

Vymazal J., Brezinova, T., 2015. The use of constructed wetlands for removal of pesticides from agricultural runoff and drainage: A review. Environment International 75 (February), 11-20.

Wieder R.K., 1989. A survey of constructed wetlands for acid coal mine drainage treatment in the eastern United States. Wetlands 9, 299-315. 